ARTICLE

https://doi.org/10.1057/s41599-019-0338-2

\title{
Determinants of international price volatility transmissions: the role of self-sufficiency rates in wheat-importing countries
}

\author{
Jin Guo ${ }^{1 \star} \&$ Tetsuji Tanaka ${ }^{1}$
}

\begin{abstract}
From the 1980s until the early 2000s, many developing governments adopted market liberalization policies due to relatively low agricultural prices and the implementation of structural programs by the IMF. Yet, a paradigm shift occurred with the emergence of the 2008 food crisis, which directed food-deficit governmental bodies to protectionist regimes supporting higher food self-sufficiency. Despite the importance of food autarky to shield domestic food markets, its effects have never been fully discussed in a formalized econometric framework. This article analyses wheat price volatility transmissions from global to local markets in 10 wheat importing countries, identifying the causality with conditional correlation functions (CCF), the degree of volatility transmissions using generalized autoregressive conditional heteroskedasticity $(\mathrm{GARCH})$ models with the dynamic conditional correlation (DCC) specification and potential determinants with a panel analysis. The main findings reveal that a significant unidirectional Granger causality runs from international wheat price to local retail flour prices for wheat importing countries with an approximate fivemonth lag, the volatility correlations from international to local markets were strengthened around the period of the 2007-08 food crisis and a higher self-sufficiency rate plays a role in alleviating volatility passthroughs from international markets. This evidence that increasing the SSR of an agricultural commodity is effective in isolating the domestic market is valuable for policymakers in food importing countries. The primary beneficiaries of implementing the policy measure are risk-averse producers and consumers because their utility or welfare improves as the price volatility of foodstuffs declines.
\end{abstract}

\footnotetext{
${ }^{1}$ Department of Economics, Setsunan University, Setsunan, Japan. *email: kaku@econ.setsunan.ac.jp
} 


\section{Introduction}

etween 2006 and 2014, global food price volatilities reduced national food security, particularly in the developing world (Ivanic and Martin, 2008), which caused social and political instability in developing regions, including Africa, Asia and South America (Bellemare, 2014) ${ }^{1}$. For example, in 2008, Haiti's senators fired the prime minister, Jacques Edouard Alexis, because he failed to decrease the price of rice (Delva and Loney, 2008). Global factors behind the food crisis such as poor grain harvests (Headey and Fan, 2008), low levels of grain stocks (Trostle, 2008), decline of investment in agricultural research and grain productivity (International Rice Research Institute, 2008; Von Braun et al., 2008), export restrictions (Von Braun et al., 2008; International Rice Research Institute, 2008; Meyers and Meyer, 2008), biofuel generated from food commodities (Von Braun et al., 2008; Headey and Fan, 2008; Mitchell, 2008; Abbott et al., 2008), energy price hikes (Yang et al., 2008; Headey and Fan, 2008) and financial speculation (Piesse and Thirtle, 2009; Cooke and Robles, 2009) were perceived as major driving forces of domestic food price inflations in importing countries rather than domestic factors. Under such national food insecurity circumstances, governments of importing nations, such as Senegal, India, the Philippines, Qatar and Bolivia, have expressed interest in increasing food self-sufficiency (Clapp, 2017).

Debates over national food autarky policies have long taken place (Hamilton, 1918; Keynes, 1993; Kako, 2009; Bishwajit et al., 2013; Clarete et al., 2013). Governmental administrations aim to enhance food self-sufficiency for various reasons such as concerns about food supply disruption due to war, extremely poor harvests by foreign producers and export restrictions, which could lead to vulnerable positions in diplomatic negotiations, environmental deterioration and the loss of concessions associated with farming or farmers (Clapp, 2015; Yamashita, 2016). However, many economists who espouse modern economic theories argue that agricultural autarky policies distort markets and create resource allocation inefficiencies (Naylor and Falcon, 2010). They also advise that subsidizing farmers or imposing additional import tariffs to hike food self-sufficiency undermine food security in the long term, precluding opportunities for gains in market efficiency (Cramer et al., 1999; Tanaka and Hosoe, 2011).

High food self-sufficiency is broadly regarded as a potent strategy for national food security by policymakers. Such a policy measure could lessen the degree of international price transmissions, which may interest aforementioned governments because this can enhance self-sufficiency rates (Tanaka, 2018). Bouët et al. (2012) discuss the rationales of export duties during global food crises, showing that export taxes contribute to stabilizing local markets.

Despite such an important policy for food security, few studies have examined the usefulness of food self-sufficiency policy using an econometric model, although some studies explore it with a general equilibrium model. Tanaka (2018) analyses the effects of wheat self-sufficiency policies for Egypt with a stochastic computable general equilibrium (CGE) model and Tanaka and Hosoe (2011) scrutinize the impact on households of a free-trade rice policy in Japan. Still, one of the major criticisms of a CGE model is that its parameters are estimated with a single-year dataset called a social accounting matrix (SAM), implying that the parameters are point-estimated and less reliable. On the contrary, an econometric model is established with longer time periods, which overcomes the primary concern of CGE.

Research has not yet fully examined the potential factors influencing the volatility pass-throughs between world and local markets in a formal statistical test. Previous studies primarily focus on the links between domestic markets within developing countries (e.g., Baulch, 1997; Abdulai, 2000; Lutz et al., 2006;
Moser et al., 2009; Myers, 2013) and only a few studies examine the transmission of price from world to local markets, including volatility transmissions (Mundlak and Larson, 1992; Conforti, 2004; Minot, 2011; Ceballos et al., 2017; Hatzenbuehler et al., 2017). Most studies adopt an error correction method to examine the relationship between global and domestic prices based on a specific country. Nevertheless, these studies did not explore determining factors of the extent of a spill-over. While, along these lines, no studies explored such factors in a comprehensive manner (such as with a panel analysis), Götz et al. (2013) discovered that Russian and Ukrainian export restrictions during food crises helped to stabilize agricultural domestic prices.

Responding to this gap in the scholarly archive, this research concentrates on examining the relationship between selfsufficiency rates and the extent of spill-over effects from global to local markets (rather than that between food policy changes and the degree of international pass-throughs). More specifically, this article explores the determinants of wheat price volatility transmissions from international to local markets using a generalized autoregressive conditional heteroskedasticity (GARCH) model with dynamic conditional correlation (DCC) specification and three types of panel regressions. We concentrate on whether wheat self-sufficiency weakens international volatility passthroughs, zooming in on 10 net importer nations that are not selfsufficient in wheat. The analysis was conducted during the period between January 2006 and December 2013. The model testing procedure is as follows. First, the direction of Granger causality was identified and the lead-lag relationships between international and domestic wheat prices using Hong's (2001) conditional correlation function (CCF). Second, the volatility correlation pairs between global and local markets were measured with the GARCH-DCC approach based on the results of leads/lags estimated in the first step. Finally, a panel data analysis was conducted to identify factors that can influence long-term dynamic correlations between international and local wheat prices in wheat-importing countries. After detecting the appropriate causalities and estimations of the three empirical models, it was successfully determined that higher self-sufficiency in wheat effectively insulates domestic markets from international market volatilities.

This article makes several contributions to the existing literature. As stated, Ceballos et al. (2017) offer the only study that investigates international price volatility transmissions of cereals. Whiles Ceballos et al. employ the GARCH-BEKK model, the first international volatility transmission analysis of an agricultural good with a DCC approach was conducted, which enabled the identification of the time variant correlated relationship between global and regional markets. One advantage of using this method is that it more precisely estimates the link between correlated volatilities and underlying factors with an extended sample size, generating yearly correlation outputs differently from a GARCHBEKK approach. This sort of factor identification econometric testing has never been performed in any prior study. In addition, this study tested the effectiveness of a self-sufficiency measure, one of the most important food security strategies that has not been econometrically examined in the literature. Furthermore, the pass-throughs with an explicit focus on the links between international wheat prices and local retail wheat flour prices were analyzed; in previous studies, it is uncertain whether the commodities focused on were wheat or wheat flour (e.g., Ceballos et al., 2017; Minot, 2011). This study aimed to fill these gaps and provide useful implications not only for policymakers, but also agricultural producers and consumers, assuming that most people are risk-averse with respect to market steadiness (Bar-Shira et al., 1994; Jianakoplos and Bernasek, 1998). 
The remainder of this article is organized as follows. Section "Data description" offers a brief description of the data. Section "Econometric methodology" introduces the empirical methods. Section "Empirical" results and interpretations addresses the empirical findings and interprets the results. Section "Conclusion and policy implications discusses the policy implications" of the results and the limitations of the study.

\section{Data description}

We used monthly data from the Global Information and Early Warning System (GIEWS), which provides the monthly food commodity prices of various countries and international food prices. Retail flour prices from January 2006 to December 2013 for 10 wheat-importing countries (Afghanistan, Azerbaijan, Brazil, Cameroon, Georgia, Israel, Kyrgyzstan, Mauritania, Peru and Tajikistan) were obtained. While commodity price data are available for a number of countries in the GIEWS, only 10 regions met the study's requirements for available data on the retail prices of wheat flour for a recent time period and of non-self-sufficiency in wheat. Following the literature, the local prices are in US dollars. The international price is the export price of wheat (US No. 2 hard red winter) from the US Gulf Coast, which is also quoted in the GIEWS. To eliminate the influence of seasonal fluctuations, we adjusted all data by using the X-13-ARIMA ${ }^{2}$ method. Moreover, for each data series, continuously compounded returns were computed as $\ln \left(X_{t} / X_{t-1}\right) \times 100$, where $X_{t}$ represents international wheat prices (IWP) and local wheat prices in 10 wheat-importing countries (Afghanistan, Azerbaijan, Brazil, Cameroon, Georgia, Israel, Kyrgyzstan, Mauritania, Peru and Tajikistan). Figure 1 plots the returns of each variable.

Table 1 reports the descriptive statistics of returns on wheat prices (international and domestic markets). Data in this table reveal that most of the mean returns are positive, suggesting a rise in wheat prices during the study period. It is worth noting that the standard deviations of Afghanistan's and Kyrgyzstan's price returns are relatively higher than those of other countries. This indicates that these two countries tend to experience extreme changes in wheat prices more frequently for the two countries. Before proceeding with the causality test based on the CCF

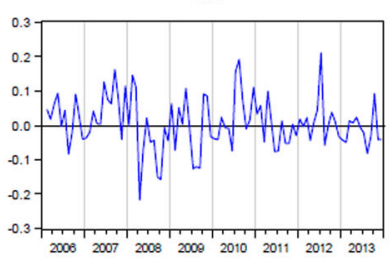

CAM
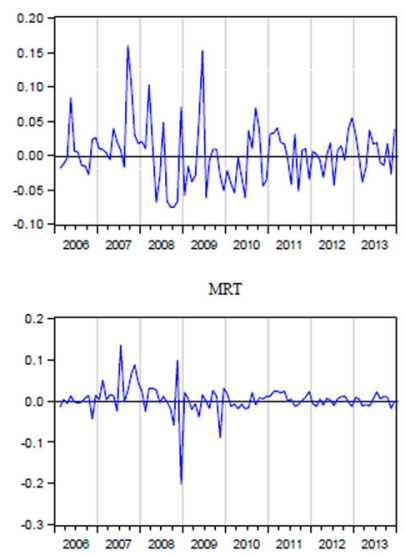

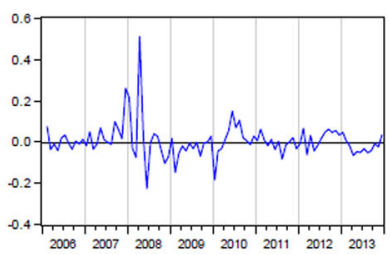

GEO
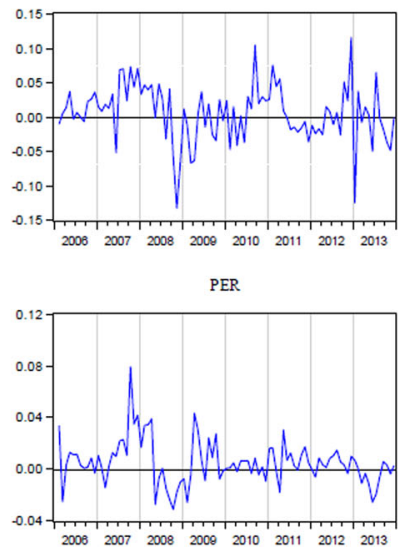

approach, it is necessary to check the stationarity of each variable An augmented Dickey-Fuller $(\mathrm{ADF})^{3}$ and Kwiatkowski-PhillipsSchmidt-Shin (KPSS) ${ }^{4}$ unit root tests were performed on the return series. The null hypothesis of the ADF test is that the series is nonstationary, whereas that of the KPSS test is that the data series is stationary. The results of the unit root tests presented in Table 1 indicate that all variables are stationary in their first logdifferenced forms ${ }^{5}$ and integrated of order 1 . This allows us to jointly model the price transmission between international and local wheat prices.In addition, Van Dijk et al. (2005) suggest pretesting for structural breaks before examining causality. Following this, Bai and Perron's (2003) structural change test, which allows for the simultaneous estimation of unknown multiple structural breaks, is applied to identify the structural break points in each wheat price series ${ }^{6}$.

The results of Bai and Perron's (2003) structural breaks test in Table 1 show that, across all countries, only Georgia demonstrates a structural break in its price returns. Specifically, one break exists in the wheat price return of Georgia in August 2008.

In the next step, we employ yearly data, including the selfsufficiency rate (SSR) and domestic economic variables, to identify the common factors that could affect wheat price volatility transmission in importing countries. Table 2 provides the definitions of the potential factor variables used and Table 3 displays the summary statistics for the explanatory variables in the panel estimation. First, because a key assumption is that the SSR could be a significant factor in determining the dynamic correlation, the annualized SSR for each country is chosen. The SSR of wheat is defined as Production/(Production + Import-Export). The data source of each component of the SSR is the FAOSTAT ${ }^{7}$. Figure 2 plots the time-series SSR in each country. As Fig. 2 and Table 3 show, the SSR displays different characteristics in wheatimporting countries. For example, Afghanistan, Kyrgyzstan and Tajikistan have relatively high average SSR values, while Cameroon's and Mauritania's SSR display the lowest average values. It is also interesting that the SSRs of some countries (e.g., Afghanistan, Azerbaijan, Brazil and Peru) fluctuated dramatically during the 2007-2008 food crisis. Because SSR data are not available at monthly frequencies, we converted the estimated

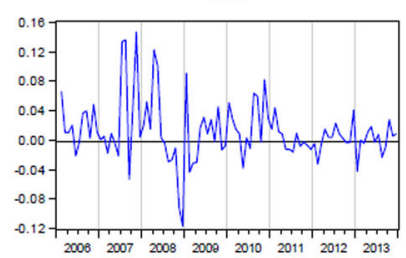

ISR
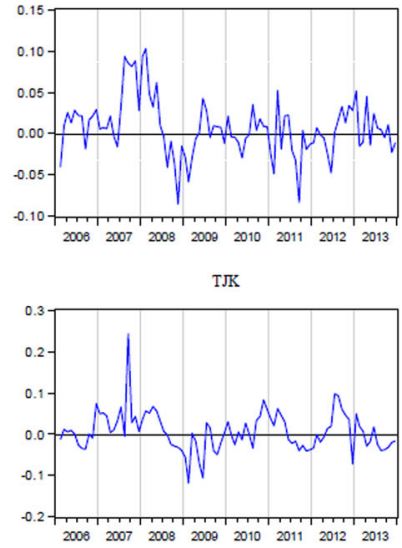

BRA

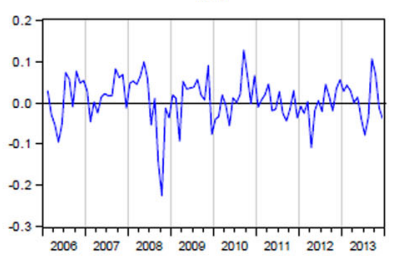

KGZ

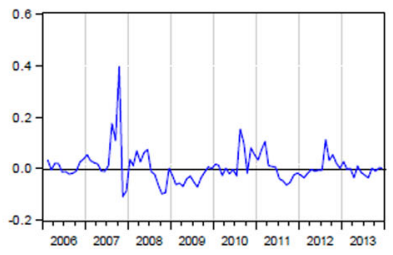

Fig. 1 Time-series plots of continuously compounded returns of international and local wheat prices 


\section{Table 1 Summary statistics and pre-test for wheat price returns}

\begin{tabular}{|c|c|c|c|c|c|}
\hline & Mean & Std. Dev. & ADF test & KPSS test & Structural break tests \\
\hline International wheat price & 0.006 & 0.076 & $-7.609^{\star \star \star}(0)$ & $0.072(2)$ & No break \\
\hline Afghanistan & 0.006 & 0.084 & $-2.950^{\star \star \star}(1)$ & $0.056(4)$ & No break \\
\hline Azerbaijan & 0.011 & 0.042 & $-3.477^{\star \star \star}(2)$ & $0.044(5)$ & No break \\
\hline Brazil & 0.006 & 0.054 & $-6.633^{\star \star \star}(0)$ & $0.036(4)$ & No break \\
\hline Cameroon & 0.003 & 0.044 & $-7.902^{\star \star \star}(0)$ & $0.091(2)$ & No break \\
\hline Georgia & 0.006 & 0.041 & $-4.520^{\star \star \star}(1)$ & $0.068(4)$ & 1 break: 2008:8 \\
\hline Israel & 0.007 & 0.035 & $-5.185^{\star \star \star}(0)$ & $0.075(6)$ & No break \\
\hline Kyrgyzstan & 0.006 & 0.064 & $-6.952^{\star \star \star}(0)$ & $0.073(4)$ & No break \\
\hline Mauritania & 0.003 & 0.035 & $-11.674^{\star \star \star}(0)$ & $0.086(5)$ & No break \\
\hline Peru & 0.005 & 0.017 & $-4.299^{\star \star \star}(6)$ & $0.041(5)$ & No break \\
\hline Tajikistan & 0.006 & 0.048 & $-3.900^{\star \star \star}(1)$ & $0.064(6)$ & No break \\
\hline
\end{tabular}

Notes: ${ }^{* * *}$ ) denotes rejection of the null hypothesis at the $1 \%$ significance level. Numbers in brackets are the lag length and bandwidth. Lag length selection was based on BIC in the ADF tests. The bandwidth for the KPSS test was determined using the Newey-West bandwidth selection algorithm (Newey and West, 1994). We implemented all the unit root tests with intercept and trend terms (this specification has the lowest BIC). We used Bai-Perron's sequential test for the hypothesis of $k$ breaks versus $k+1$ breaks, employing the F-statistics. Lag length selection was based on BIC in the test

Table 2 Definitions of the variables in the panel analysis

Variable names

$D C C_{i, t}$

$\mathrm{SSR}_{i, t}$

$G D P_{i, t}$

$C P I_{i, t}$

$M C_{i, t}$

$R C_{i, t}$
Definition

Dynamic conditional correlation of wheat between international and country i's domestic price with one lag at Estimated by Author time $t$.

Self-sufficiency rate of wheat in country $i$ at time $t$.

Real GDP per capita growth rate in country $i$ at time $t$.

Inflation rate in country $i$ at time $t$.

Domestic consumption of maize in country $i$ at time $t$

Domestic consumption of rice in country $i$ at time $t$.

\section{Source}

FAOSTAT

FAOSTAT

World Bank

FAOSTAT

FAOSTAT monthly conditional correlations between international and local prices into yearly frequency data ${ }^{8}$.

Moreover, it is important to consider the substitutive effects of commodities; therefore, the annualized domestic consumption of maize and rice in each wheat-importing country were selected. Table 4 shows the levels of domestic consumption of wheat, rice and maize in each country. Wheat consumption is typically larger than those of maize and rice in all countries except Cameroon and Peru. In addition, we include macroeconomic factors-the annualized GDP per capita growth rate and annualized inflation rate $^{9}$ - to reflect the current economic conditions. The GDP and CPI data are sourced from FAOSTAT and the World Bank's World Development Indicators online database ${ }^{10}$.

\section{Econometric methodology}

To perform the analysis, we used a three-step econometric methodology. First, we examined the Granger causality and leadlag relationships between international and local wheat prices by employing the CCF approach. Second, we estimated the price volatility transmission between international and local wheat markets using a GARCH-DCC framework. In the final step, a panel analysis was applied to investigate the common factors that could affect wheat price volatility transmission in wheatimporting countries.

Testing Granger causality using a cross-correlation function. To examine the causality between international and local wheat prices in wheat-importing countries, Hong's (2001) non-uniform weighting cross-correlation function (CCF) was applied. One of the key advantages of this approach is that it can detect the leading and lagging structures of causality, as well as the duration over which causality is exerted ${ }^{11}$. The GARCH used in this model was introduced by Bollerslev (1986) ${ }^{12}$ and has been widely used to estimate volatilities for time-series data ${ }^{13}$. Using the residuals obtained from the GARCH model, the standardized residuals $\hat{\tau}_{t}$ and $\hat{\xi}_{t}$ were estimated. Next, the sample cross-correlation coefficient at lag $m, \hat{r}_{\tau \xi}(m)$, was calculated from the consistent estimates of the conditional mean and variance for international and local wheat prices. This leaves us with

$$
\hat{r}_{\tau \xi}(m)=\hat{c}_{\tau \xi}(m)\left\{\hat{c}_{\tau \tau}(0) \hat{c}_{\xi \xi}(0)\right\}^{-\frac{1}{2}}
$$

where $\hat{c}_{\varepsilon \xi}(m)$ is the $m$-th lag sample cross-covariance given by

$$
\hat{c}_{\tau \xi}(m)=\left\{\begin{array}{l}
T^{-1} \sum_{t=j+1}^{T} \hat{\tau}_{t} \hat{\xi}_{t-j} \text { for } j \geq 0 \\
T^{-1} \sum_{t=-j+1}^{T} \hat{\tau}_{t+1} \hat{\xi}_{t} \text { for } j<0
\end{array},\right.
$$

where $\hat{c}_{\tau \tau}(0)$ and $\hat{c}_{\xi \xi}(0)$ are defined as the sample variances of $\hat{\tau}_{t}$ and $\hat{\xi}_{t}$, respectively and $T$ is the sample size.

Causality in the mean of international and local wheat prices can be tested by examining $\hat{r}_{\tau \xi}(m)$, the univariate standardized residual CCF. Under the regularity condition ${ }^{14}$, the following holds:

$$
S=T \sum_{i=1}^{k} \hat{r}_{\tau \xi}^{2}(i) \stackrel{L}{\longrightarrow} \chi^{2}(k),
$$

where $\stackrel{L}{\longrightarrow}$ shows convergence in distribution and $\chi^{2}(k)$ indicates a chi-square distribution with $k$ degrees of freedom. To test for a causal relationship from lag 1 to $k$, the $S$-statistic was compared with the chi-square distribution. If the test statistic was higher than the critical value of the chi-square distribution, the null hypothesis. Furthermore, Hong (2001) indicates that the $S$ statistic weighs each lag uniformly; therefore, it may distort the amount of the presence of causality. Thus, Hong's (2001) method was adopted, incorporating the weighting cross-correlation, which is consistent with the intuition that more recent 


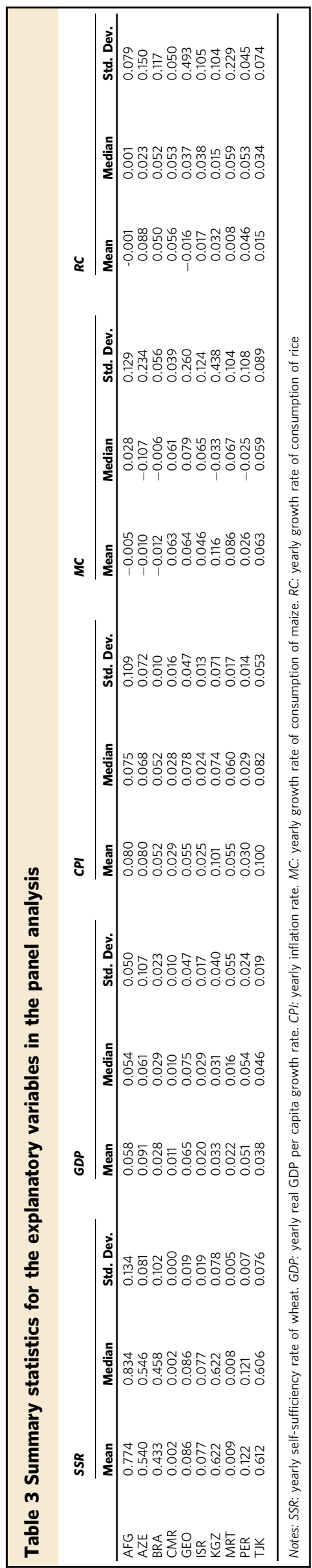

information should be heavily weighted. The modified test statistics are defined as

$$
Q=\frac{S-k}{\sqrt{2 k}} \stackrel{L}{\longrightarrow} N(0,1) .
$$

The Q-statistic is assumed to follow an upper-tail normal distribution. This test allowed for more flexible specifications of the innovation and was suitable for analyzing the lead-lag causal relationships between two variables.

Estimating price volatility transmission by applying the GARCH-DCC model. In recent years, multivariate GARCH (MGARCH) models with dynamic covariance and conditional correlation have been shown to be more useful in analyzing volatility spill-over mechanisms ${ }^{15}$ and thus this method was used for analysis. The econometric framework of the GARCH-DCC model was formulated as follows: let $p_{t}$ be a $2 \times 1$ vector of returns including the international wheat price $p_{1, f}$ and local wheat price $p_{2, f}$. Thus, an autoregression (AR) model $k$ process for $p_{t}$ conditional on the information set $\Omega_{t-1}$ can be represented as:

$$
\begin{gathered}
p_{t}=\mu+\sum_{i=1}^{k} \phi_{i} p_{t-i}+u_{t}=\mu+\sum_{i=1}^{k} \phi_{i} p_{t-i}+\sqrt{H_{t}} z_{t}, \\
u_{t} \mid \Omega_{t-1} \sim N\left(0, H_{t}\right), \\
H_{t}=E\left[u_{t} u_{t}^{\prime}\right]=D_{t} P_{t} D_{t},
\end{gathered}
$$

where $\mu=\left(\mu_{1}, \mu_{2}\right)^{\prime}$ is the vector of conditional means, $\phi_{i}$ is the parameter vector, $k$ is the lag lengths of the mean equations, $u_{t}=\left(u_{1, t}, u_{2, t}\right)^{\prime}$ is the vector of innovations, $H_{t}$ is a $2 \times 2$ conditional variance-covariance matrix, $z_{t}$ is a $2 \times 1$ i.i.d vector of standardized residuals, $D_{t}$ is the diagonal matrix containing the conditional standard deviations on the diagonal and $P_{t}$ is the conditional correlation matrix given by:

$$
P_{t}=\operatorname{diag}\left(q_{11, t}^{-1 / 2}, q_{22, t}^{-1 / 2}\right) Q_{t} \operatorname{diag}\left(q_{11, t}^{-1 / 2}, q_{22, t}^{-1 / 2}\right),
$$

where $Q_{t}$ is the conditional correlation matrix of standardized residuals and $q$ is the element of matrix $Q_{t}$. Moreover, the matrix $D_{t}$ can be obtained by estimating a univariate $\operatorname{GARCH}(p, q)$ model, with $\sqrt{h_{i, t}}(i=1,2)$ on the $i t h$ diagonal as follows:

$$
h_{i, t}=\pi_{i, 0}+\sum_{p=1}^{p_{i}} \lambda_{i, p} u_{i, t-p}^{2}+\sum_{q=1}^{q_{i}} \gamma_{i, q} h_{i, t-q},
$$

where $h_{i, t}$ is a $2 \times 1$ conditional variance vector of the price series and $\pi_{i, 0}$ is a $2 \times 1$ constant vector, the lag lengths of variance equations are represented as $p$ and $q$ and $\lambda$ and $\gamma$ are the parameters of the GARCH and ARCH terms, respectively

Furthermore, Engle's (2002) DCC model and Cappiello et al.'s (2006) asymmetric DCC (henceforth, A-DCC) ${ }^{16}$ model were used to determine the volatility spill-over between international and local wheat prices in wheat-importing countries. Meanwhile, the generalized DCC (henceforth, G-DCC) and asymmetric generalized DCC (henceforth, AG-DCC) models ${ }^{17}$ were employed and the best model was selected based on the Bayesian-Schwarz information criterion (henceforth, BIC). According to Engle (2002), the dynamic correlation structure is given as:

$$
Q_{t}=(1-\alpha-\beta) \bar{P}+\alpha \nu_{t-1} v_{t-1}^{\prime}+\beta Q_{t-1},
$$

where $Q_{t}$ is a symmetric positive definite matrix in Eq. (8) and $\bar{P}$ is the $2 \times 2$ unconditional correlation matrix of the standardized residuals $v_{t}$. The parameters $\alpha$ and $\beta$ are non-negative, with a sum of less than unity. Therefore, the trend of the G-DCC model can 

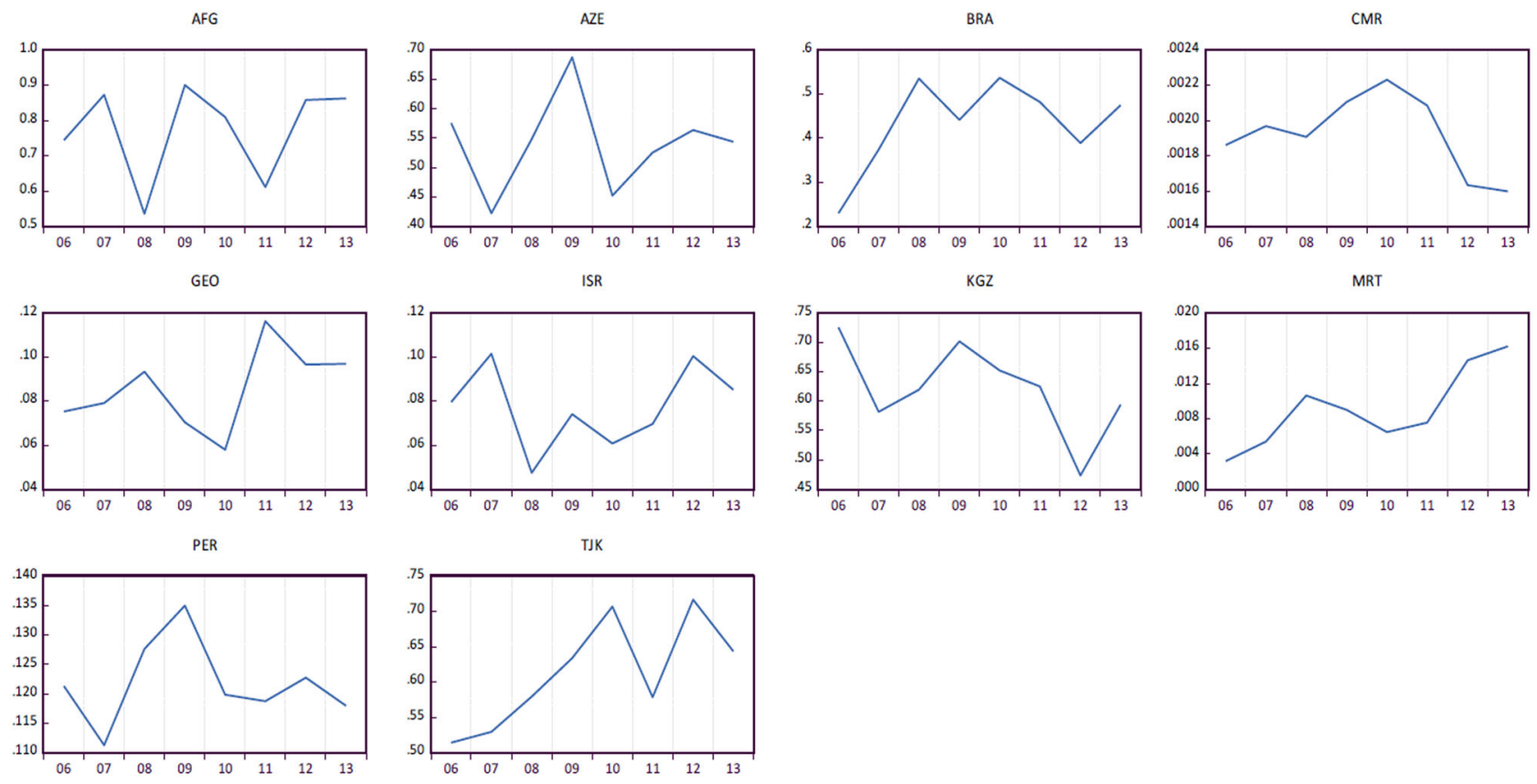

Fig. 2 Time-series plots of SSR for wheat in importing countries

\begin{tabular}{|c|c|c|c|c|c|c|c|c|c|c|}
\hline & AFG & AZE & BRA & CMR & GEO & ISR & KGZ & MRT & PER & TJK \\
\hline Maize & 21 & 99 & 240 & 325 & 243 & 99 & 195 & 28 & 185 & 21 \\
\hline Rice & 141 & 21 & 326 & 239 & 27 & 165 & 72 & 481 & 519 & 141 \\
\hline
\end{tabular}

be specified as:

$$
Q_{t}=\left(\bar{P}-A^{\prime} \bar{P} A-B^{\prime} \bar{P} B\right)+A^{\prime} \nu_{t-1} \nu_{t-1}^{\prime} A+B^{\prime} Q_{t-1} B
$$

where $A$ and $B$ are $2 \times 2$ parameter matrices and $\bar{P}$ is estimated by using the sample analogue $T^{-1} \sum_{t=1}^{T} \nu_{t} v_{t}^{\prime}$. To introduce the presence of asymmetries into the DCC model, Cappiello et al. (2006) modified the correlation evolution equations in the following expression:

$$
Q_{t}=(1-\alpha-\beta) \bar{P}-\delta \bar{N}+\alpha\left(\nu_{t-1} \nu_{t-1}^{\prime}\right)+\beta Q_{t-1}+\delta\left(\eta_{t-1} \eta_{t-1}^{\prime}\right)
$$

where $\bar{N}$ represents the unconditional matrices of $\eta_{t}=I\left[\nu_{t}<0\right] \otimes \nu_{t}, I[$.$] an indicator function equal to 1$ if $\nu_{t}<0$ and 0 otherwise and ' $\otimes$ ' the Hadamard product. Equation (12) is a standard A-DCC in which asymmetric terms are included. Thus, the AG-DCC model can be expressed as:

$$
\begin{aligned}
Q_{t}= & \left(\bar{P}-A^{\prime} \bar{P} A-B^{\prime} \bar{P} B\right)-G^{\prime} \bar{N} G+A^{\prime} \nu_{t-1} \nu_{t-1}^{\prime} A \\
& +B^{\prime} Q_{t-1} B+G^{\prime} \eta_{t-1} \eta_{t-1}^{\prime} G
\end{aligned}
$$

where $A, B$ and $N$ are parameter metrics. In the estimation, $\bar{N}$ is replaced with a sample analogue, $T^{-1} \sum_{t=1}^{T} \eta_{t} \eta_{t}^{\prime}$. It is worth noting that the AG-DCC model in Eq. (13) nests several specifications of these DCC, G-DCC and A-DCC models. In addition, the correlation coefficient $\rho_{12}$ at time $t$ can be defined as:

$$
\rho_{12, t}=\frac{q_{12, t}}{\sqrt{q_{11, t} q_{22, t}}} .
$$

Finally, the parameters of the DCC, G-DCC, A-DCC, and AGDCC models were estimated by employing the Gaussian quasimaximum likelihood estimation (QMLE) ${ }^{18}$ with the $\mathrm{BFGS}^{19}$ optimization algorithm. The joint $\log$-likelihood function $L(\theta, \psi)$ can be written as the sum of a volatility part and a correlation part, expressed as:

$$
L(\theta, \psi)=-\frac{1}{2} \sum_{t-1}^{T}\left(N \log (2 \pi)+2 \log \left|D_{t}\right|+\log \left|P_{t}\right|+v_{t}^{\prime} P_{t}^{-1} \nu_{t}\right),
$$

where $T$ refers to the number of observations and $N$ denotes the number of equations. Moreover, the univariate GARCH parameters in $D_{t}$ are denoted as $\theta$, where $\theta=(\pi, \lambda, \gamma)$ and the dynamic correlation parameters in $P_{t}$ are denoted as $\Psi$, where $\Psi=(\alpha, \beta, \delta)$. The time-varying conditional correlation coefficients are computed based on each GARCH-DCC model.

Identifying factors using panel analysis. In the final step, the underlying factors that influence wheat price volatility transmission from international to local markets in wheat-importing countries were investigated. To tackle the data limitation problems, a panel data approach was taken and wheat-importing countries were regarded as a whole to analyze the factors 
Table 5 Empirical results of AR-GARCH model

\begin{tabular}{|c|c|c|c|c|c|c|c|}
\hline & \multicolumn{3}{|l|}{ Parameters } & \multirow[b]{2}{*}{ Dummy } & \multicolumn{3}{|c|}{ Specification tests } \\
\hline & $\phi$ & $\lambda$ & $\gamma$ & & Ljung-Box (12) & LM test & BIC \\
\hline International wheat price & $0.217^{\star \star}$ & 0.028 & $0.852^{\star \star \star}$ & - & 4.947 & 0.067 & -2.160 \\
\hline Afghanistan & 0.012 & $0.298^{\star \star \star}$ & $0.712^{\star \star \star}$ & - & 16.301 & 0.171 & -2.290 \\
\hline Azerbaijan & 0.046 & $0.348^{\star}$ & $0.607^{\star \star \star}$ & - & 6.543 & 0.696 & -3.631 \\
\hline Brazil & $0.315^{\star \star \star}$ & $-0.062^{\star}$ & $1.039^{\star \star \star}$ & - & 5.049 & 0.471 & -3.129 \\
\hline Cameroon & $0.189^{\star \star}$ & 0.086 & $0.900^{\star \star \star}$ & - & 2.284 & 0.004 & -3.331 \\
\hline Georgia & 0.194 & $-0.019^{\star \star}$ & $0.563^{\star \star}$ & $0.448^{\star \star}$ & 6.411 & 0.117 & -3.500 \\
\hline Israel & $0.438^{\star \star \star}$ & $0.363^{\star}$ & $0.464^{\star \star}$ & - & 8.173 & 0.033 & -4.058 \\
\hline Kyrgyzstan & $0.639^{\star \star \star}$ & 0.251 & $0.624^{\star \star}$ & - & 8.198 & 0.018 & -3.403 \\
\hline Mauritania & -0.044 & $0.550^{\star}$ & $0.467^{\star \star}$ & - & 3.581 & 0.001 & -4.356 \\
\hline Peru & $0.339^{\star \star \star}$ & 0.249 & $0.610^{\star}$ & - & 1.826 & 0.239 & -5.491 \\
\hline Tajikistan & $0.728^{\star \star \star}$ & $0.775^{\star \star \star}$ & 0.012 & - & 7.053 & 0.078 & -3.426 \\
\hline \multicolumn{8}{|c|}{$\begin{array}{l}\text { Notes: }(*),\left({ }^{*}\right) \text {, and }\left({ }^{* *}\right) \text { denote statistical significance at the } 10 \%, 5 \% \text {, and } 1 \% \text { levels, respectively. The lag length } k \text { in the AR model, the ARCH term } p \text { and the GARCH term } q \text { in the GARCH models were } \\
\text { selected from among } k=1,2, \ldots, 10, p=1,2 \text { and } q=1,2,23 \text { respectively, by applying the BIC and residual diagnostics }{ }^{24} \text {. The standard error follows Bollerslev and Wooldridge's }(1992) \text { robust standard } \\
\text { error. Diagnostic test: Ljung-Box's statistics for the null hypotheses of no autocorrelation up to the order of } 12 \text { for standardized residuals (Ljung and Box, } 1978 \text { ). The statistics indicate that the null } \\
\text { hypothesis of no autocorrelation up to the order of } 12 \text { for the standard residuals cannot be rejected at the } 1 \% \text { significance level. LM test: the Lagrange multiplier (LM) test statistic for ARCH in residuals } \\
\text { (distributed as chi-square). The LM test statistic indicates that the null hypothesis of no further ARCH effect in the residuals cannot be rejected }\end{array}$} \\
\hline
\end{tabular}

influencing price volatility transmission. Following the specification in Table 2, the following panel regression model was constructed:

$$
\begin{aligned}
\mathrm{DCC}_{i, t}= & c+\kappa_{1} \mathrm{SSR}_{i, t}+\kappa_{2} \mathrm{GDP}_{i, t}+\kappa_{3} \mathrm{CPI}_{i, t} \\
& +\kappa_{4} \Delta \mathrm{MC}_{i, t}+\kappa_{5} \Delta \mathrm{RC}_{i, t}+\varepsilon_{i, t},
\end{aligned}
$$

where DCC is the dynamic conditional correlations at yearly frequency; $c$ the constant; $\varepsilon_{i, t}$ is the heteroskedastic error term; GDP and CPI annualized GDP per capita growth rate and inflation rate, respectively; $\mathrm{MC}$ and $\mathrm{RC}$ the log-transformed values of maize and rice consumption, respectively; $\Delta$ the first difference and $k$ the parameters to be estimated. These parameters measure the impact of the common factors that influence the price volatility transmission ${ }^{20}$.

Before performing the panel analysis, it was necessary to consider the impact of heteroskedasticity or serial correlation in the error term and any cross-sectional dependence in the crosscountry panel. Therefore, a series of pre-tests was applied. Specifically, the modified Wald test (Wooldridge, 2010), Pesaran's test (Pesaran, 2004) and Wooldridge's test (Wooldridge, 2010) were employed for heteroskedasticity, cross-sectional correlation and autocorrelation, respectively. Notably, in a standard panel data estimation, the fixed effect model or random effect model is used to estimate the parameters. Hausman's test was thus used to examine the appropriateness of the fixed effect model relative to the random effect model.

The feasible generalized least-squares (FGLS) regression was used to estimate the panel model. The advantage of the FGLS method is that it allows for heteroskedasticity or autocorrelation in the error term. Moreover, Monte Carlo studies ${ }^{21}$ have shown that the FGLS estimator generally yields better estimates than the ordinary least-squares (OLS) estimator. To guarantee the robustness of the empirical results, the Prais-Winsten regression with panel-corrected standard errors (PCSEs) was applied to compare the results. As Beck and Katz (1995) argue, a PCSE model leads to a more accurate estimation than an FGLS model.

\section{Empirical results and interpretations}

The causal relationship between global and local wheat prices. As made clear above, in this study, each model was estimated using the maximum likelihood method and the lag lengths of the mean and variance equations were determined based on BIC. The AR (1)-GARCH $(1,1)$ model was chosen for each price series because it had the lowest BIC value ${ }^{22}$. Because structural break dates were identified in Georgia's data, a dummy variable was included in its model. Table 5 shows the parameter estimates for each model and their corresponding statistical significance values. First, we can observe that most of the coefficients of the ARCH $(\lambda)$ and GARCH $(\gamma)$ are significant in the GARCH model. Notably, the coefficient of the dummy variables for Georgia is significant at the $5 \%$ level. This suggests that the dummy variable accommodates the structural break in Georgia's data. Following the result, this structural break should be interpreted as the military conflict that broke out between Russia and Georgia in August 2008. It strongly suggests that this short war appears to have significantly affected Georgia's wheat market and caused the structural change in domestic wheat products and prices. Furthermore, it is noticeable that the break points in the global wheat price and most local wheat prices in importing countries were not discovered. These results imply that little evidence exists to support the structural changes in the wheat price returns during the 2007-2008 food crisis. In addition, Table 5 shows the diagnostics of the empirical results. All the tests imply that the estimated models adequately fit the data.

Next, based on the CCF approach, the standardized residuals obtained from each GARCH model were used to examine the causal relationship between international and local prices. Table 6 presents the empirical results, which show that international wheat price returns demonstrate a Granger causality in local prices in all wheat-importing countries with a five-month $\operatorname{lag}^{25}$. In turn, there is no statistically significant evidence of causality from local price to international price ${ }^{26}$. Therefore, it can be concluded that a unidirectional causality exists from international to local prices in the sample, suggesting that international price can be considered a leading indicator of local price in wheatimporting countries ${ }^{27}$. Based on these results, the local price of each wheat-importing country was lagged by five periods (five months) to capture the information from the global market to the local market with a five-month time lag.

Dynamic conditional correlations between global and local wheat prices. In the second stage, as mentioned in the methodology section, standardized residuals obtained from the GARCH model were used to estimate the conditional cross-correlation coefficient $\rho_{12, f}$ in Eq. (14). Table 7 gives the estimation results of the parameter metrics for all the DCC models. First, the necessary condition of $\alpha+\beta<1$ holds for nearly every pair of international and local prices in the DCC and A-DCC models, indicating that 
Table 6 Results for Hong's (2001) Granger causality test

\begin{tabular}{|c|c|c|c|c|}
\hline \multirow[b]{2}{*}{$\boldsymbol{m}=\mathbf{5}$} & \multicolumn{2}{|c|}{ Causality-in-mean } & \multicolumn{2}{|c|}{ Causality-in-variance } \\
\hline & Q-statistic & $P$-value & Q-statistic & P-value \\
\hline $\mathrm{IWP} \rightarrow \mathrm{AFG}$ & $2.251^{\star \star}$ & 0.024 & 1.073 & 0.283 \\
\hline $\mathrm{AFG} \rightarrow \mathrm{IWP}$ & -0.045 & 0.964 & -0.329 & 0.742 \\
\hline IWP $\rightarrow$ AZE & $3.673^{\star \star \star}$ & 0.000 & -0.678 & 0.498 \\
\hline $\mathrm{AZE} \rightarrow \mathrm{IWP}$ & -0.861 & 0.389 & 0.551 & 0.581 \\
\hline $\mathrm{IWP} \rightarrow \mathrm{BRA}$ & $2.229^{\star \star}$ & 0.026 & 0.222 & 0.824 \\
\hline BRA $\rightarrow$ IWP & 0.523 & 0.601 & 0.374 & 0.709 \\
\hline $\mathrm{IWP} \rightarrow \mathrm{CMR}$ & $2.140^{\star \star}$ & 0.032 & $2.417^{\star \star}$ & 0.016 \\
\hline $\mathrm{CMR} \rightarrow \mathrm{IWP}$ & 1.010 & 0.312 & -0.027 & 0.978 \\
\hline IWP $\rightarrow$ GEO & $2.588^{\star \star}$ & 0.010 & 0.351 & 0.726 \\
\hline $\mathrm{GEO} \rightarrow \mathrm{IWP}$ & -0.426 & 0.670 & -0.829 & 0.407 \\
\hline$I W P \rightarrow I S R$ & $3.303^{\star \star \star}$ & 0.001 & 0.205 & 0.837 \\
\hline $\mathrm{ISR} \rightarrow \mathrm{IWP}$ & 0.086 & 0.932 & 0.791 & 0.429 \\
\hline $\mathrm{IWP} \rightarrow \mathrm{KGZ}$ & $3.487^{\star \star \star}$ & 0.000 & $2.945^{\star \star \star}$ & 0.003 \\
\hline $\mathrm{KGZ} \rightarrow \mathrm{IWP}$ & 0.371 & 0.711 & -0.544 & 0.587 \\
\hline $\mathrm{IWP} \rightarrow \mathrm{MRT}$ & $2.512^{\star \star}$ & 0.012 & -0.397 & 0.692 \\
\hline $\mathrm{MRT} \rightarrow \mathrm{IWP}$ & 0.395 & 0.693 & -0.825 & 0.409 \\
\hline IWP $\rightarrow$ PER & $2.391^{\star \star}$ & 0.017 & 1.073 & 0.283 \\
\hline $\mathrm{PER} \rightarrow \mathrm{IWP}$ & -0.641 & 0.521 & -0.329 & 0.742 \\
\hline IWP $\rightarrow$ TJK & $1.712^{\star}$ & 0.080 & -1.006 & 0.315 \\
\hline $\mathrm{TJK} \rightarrow \mathrm{IWP}$ & -0.439 & 0.847 & -0.564 & 0.573 \\
\hline
\end{tabular}

the dynamic conditional correlations are mean reverting for international and local prices. Second, the parameters, $\beta$, were observed to be mostly positive and significant in the DCC and ADCC models. This indicates that the lagged dynamic conditional correlation significantly affects the current dynamic conditional correlations. Third, the asymmetry coefficients, $\eta$, are found to be significant in Afghanistan and Peru in the A-DCC model, thereby providing evidence of an asymmetric response in correlation for the two countries. Next, the most appropriate model for each country was selected based on BIC. Table 8 presents the results of the model selection, which show that the standard DCC model is selected as the best fit to Afghanistan, Georgia, Kyrgyzstan, Peru and Tajikistan and the G-DCC model is chosen for Azerbaijan, Brazil, Cameroon, Israel and Mauritania.

Finally, the dynamic cross-correlation coefficients can be estimated by maximizing the log-likelihood functions in Eq. (15). Figure 3 plots the evolution of the estimated time-varying dynamic correlations of each country. Overall, it is interesting to ascertain that all conditional correlations display considerable variability in the sample period and exhibit different patterns across different countries. Figure 3 visually confirms that almost all the conditional correlation coefficients (except those of Afghanistan, Cameroon, Israel and Tajikistan) are positive throughout the entire sample period. Because the wheatimporting countries' SSRs in the sample are less than 1 (net wheat-importing countries), it is not surprising that global wheat prices significantly affect local wheat prices in these countries. Moreover, it is interesting that some countries' dynamic correlations fluctuated dramatically during the 2007-2008 global food crisis. Specifically, a substantial increase in correlation between global and local wheat markets is apparent at the beginning of the food crisis, offering further evidence of the strong impacts of global wheat prices on local prices in some countries (e.g., Azerbaijan, Brazil, Georgia, Israel, and Mauritania). Since a structural break was found in Georgia, it is necessary

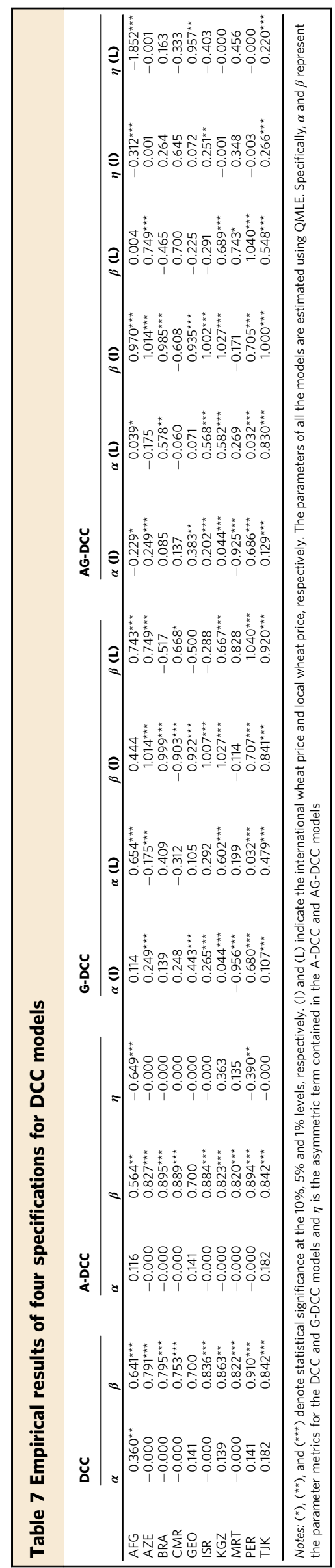


to check whether significant trade policy changes occurred in Georgia during the crisis. Table 9 reports Georgia's import tariff for cereals from 2006 to 2013. It was observed that Georgia's trade tariff rate was lowered from $6.4 \%$ to $0.3 \%$ in 2007 . This policy change seems to have increased the correlation between international and local prices in Georgia. For a country such as Georgia, the autarky rate of which is extremely $\operatorname{low}^{28}$, one of the best short-term counter strategies to feed citizens is to liberalize food imports rather than to raise import tariffs.

Table 10 provides the descriptive statistics for the 10 wheatimporting countries' dynamic correlations. First, the means of the correlations are positive in all countries. This suggests that increases or declines in the volatility of international wheat prices can cause increases or declines in the volatility of domestic wheat prices in wheat-importing countries. Brazil has the highest average value (0.359) of dynamic correlation coefficients, which broadly indicates that Brazil's domestic wheat price has a high

\section{Table 8 The model selection of four specifications for DCC models}

\begin{tabular}{|c|c|c|c|c|}
\hline & \multicolumn{4}{|l|}{ BIC criterion } \\
\hline & DCC & A-DCC & G-DCC & AG-DCC \\
\hline$\overline{\mathrm{AFG}}$ & $-391.117^{\star}$ & -388.464 & -383.056 & -379.020 \\
\hline AZE & - & -533.733 & $-537.335^{\star}$ & -528.250 \\
\hline BRA & - & - & $-468.264^{\star}$ & -459.710 \\
\hline CMR & - & - & $-507.199^{\star}$ & -498.531 \\
\hline GEO & $-522.106^{\star}$ & -517.563 & -516.417 & -508.537 \\
\hline ISR & - & - & $-566.537^{\star}$ & -560.248 \\
\hline KGZ & $-461.359^{\star}$ & -457.708 & -455.269 & -446.196 \\
\hline MRT & - & -588.398 & $-586.404^{\star}$ & -577.758 \\
\hline PER & $-704.725^{\star}$ & -702.392 & -698.556 & -689.479 \\
\hline TJK & $-497.645^{\star}$ & -493.102 & -489.168 & -481.935 \\
\hline
\end{tabular}

Notes: $\left(^{*}\right)$ denotes the lowest value of BIC. - denotes that the dynamic conditional correlation cannot be calculated. It is observed that the DCC models demonstrate the lowest BIC values for Afghanistan, Georgia, Kyrgyzstan, Peru, and Tajikistan and that the G-DCC models demonstrate the lowest BIC values for Azerbaijan, Brazil, Cameroon, Israel, and Mauritania correlation with international wheat prices. On the other hand, Tajikistan has the lowest average value (0.024), which conveys a relatively low correlation. Furthermore, as Table 10 shows, different magnitudes of correlation variability emerge across different wheat-importing countries. In particular, Azerbaijan's correlation coefficients fluctuated more than those of other countries and thus demonstrated the highest standard deviation (0.150). Conversely, Mauritania's dynamic correlation coefficients are the most stable and thus demonstrated the lowest standard deviation (0.011).

Panel data analysis. To investigate the common factors that impact the price volatility transmission, the panel model was estimated based on Eq. (16). As mentioned in the "Econometric methodology" section of the methods, some pre-tests need to be specified in a preliminary step. Table 11 summarizes the pre-test results. The Hausman test suggests a random effects model for running the panel regression instead of a fixed effects model. Furthermore, the results indicate that the model exhibits heteroskedasticity, serial correlation and cross-sectional dependencies.

Based on the results of the specification tests, a random effects model was employed as the base model.

Table 12 reports the empirical results of the panel regression based on these three model specifications. The empirical results revealed several interesting findings. First, it was verified that the coefficients of SSR are negative and significant for all models. These results confirm that the self-sufficiency rate of wheat is a determining factor affecting the dynamic conditional correlation between international and local wheat prices in wheat-importing countries. Furthermore, the negative coefficient indicates that an increase in the SSR will decrease the dynamic correlations. This suggests that raising the SSR of wheat can be a reasonable strategy to buffer importing countries from excessive fluctuations in international wheat prices. Second, the panel results show that the coefficients of CPI are negative and significant for the PCSEs and FGLS models. Theoretically, an increase in the inflation rate will decrease the real value of currency in local countries, which in
BRA

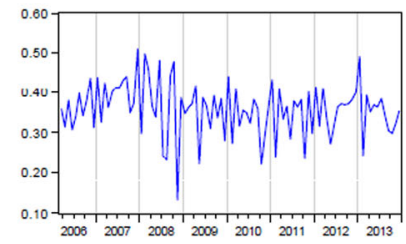

KGZ

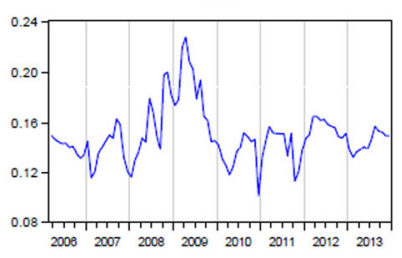

CMR

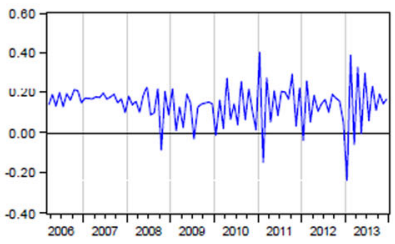

MRT

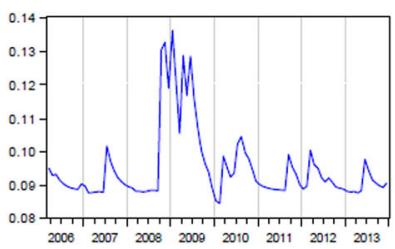

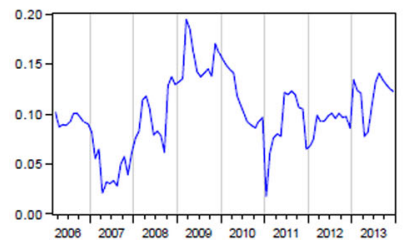

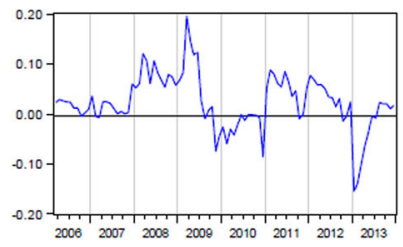

Fig. 3 Plots of dynamic correlations between international and domestic wheat prices 
turn weakens purchasing power and amplifies correlation with the global wheat market. One possible explanation for the negative sign of CPIs coefficients is that some monopoly or oligopoly exists among wheat importers. They may weaken the price transmission to local wheat markets if international prices decrease. Third, the results show that the coefficients of GDP are not robust to model change $\left(k_{2}\right.$ is positive and significant only in the FGLS model). GDP per capita growth represents the livelihood of nationals, which may accelerate volatility passthroughs because wealthier citizens tend to import more foodstuffs. For instance, Israel has the higher GDP per capita and one of the lowest SSRs ${ }^{29}$. Because the results of CPI and GDP are not robust against a change in the model selection, they may not be the more important factors in determining the degree of price volatility transmission. Finally, it is interesting that the coefficients of $\triangle M C$ and $\triangle R C$ are mostly not significant across different estimation methods, implying that a substitutive effect does not exist between wheat, maize and rice. Typically, substituting the consumption of a good that becomes more expensive with one that is relatively cheap could buffer price shocks transmitted from external markets, causing demand for the expensive product to fall. For instance, the high price of wheat induces substitution behavior between cereal goods such as rice and maize, which may partly prevent volatility conveyances. A potential explanation for the findings might be that very different food preferences exist in

\begin{tabular}{|c|c|}
\hline Year & Import tariff (percent) \\
\hline 2006 & 6.4 \\
\hline 2007 & 0.3 \\
\hline 2008 & 0.3 \\
\hline 2009 & 0.3 \\
\hline 2010 & 0.3 \\
\hline 2011 & 0.7 \\
\hline 2012 & 0.6 \\
\hline 2013 & 0.7 \\
\hline
\end{tabular}

Table 10 Summary statistics for dynamic conditional correlations of wheat

\begin{tabular}{llllcl} 
& Mean & Median & Maximum & Minimum & Std. Dev. \\
\hline Afghanistan & 0.119 & 0.115 & 0.472 & -0.166 & 0.101 \\
Azerbaijan & 0.275 & 0.246 & 0.996 & 0.009 & 0.150 \\
Brazil & 0.359 & 0.363 & 0.509 & 0.132 & 0.066 \\
Cameroon & 0.140 & 0.155 & 0.402 & -0.239 & 0.101 \\
Georgia & 0.267 & 0.266 & 0.394 & 0.199 & 0.023 \\
Israel & 0.212 & 0.180 & 0.766 & -0.065 & 0.136 \\
Kyrgyzstan & 0.150 & 0.147 & 0.228 & 0.102 & 0.022 \\
Mauritania & 0.095 & 0.091 & 0.136 & 0.085 & 0.011 \\
Peru & 0.101 & 0.099 & 0.194 & 0.017 & 0.036 \\
Tajikistan & 0.024 & 0.023 & 0.195 & -0.156 & 0.055 \\
\hline
\end{tabular}

different countries. Compared with maize and rice, wheat accounts for a huge amount of domestic demand (e.g., as in Afghanistan, Azerbaijan, Israel, Kyrgyzstan, and Tajikistan) ${ }^{30}$. This phenomenon might cause a lower price elasticity of demand in wheat markets. Therefore, it is reasonable to consider that cultural, religious, or demographic factors may be more formative than the price of food in consumers' food choices.

\section{Conclusion and policy implications}

This article explored potential factors of international wheat volatility transmissions using econometric methods such as the CCF, GARCH-DCC and panel data analysis. The primary findings are as follows. First, the analysis found a significant unidirectional Granger causality of wheat price running from international to local markets with approximately five months of lag length as the countries analyzed in this article are small wheat producers that cannot influence international prices. Second, the results show positive dynamic conditional correlations between international and local wheat prices for most wheat-importing countries. It is concluded that the international wheat price considerably affects the local price in wheat-importing countries. Third, it was found that the self-sufficiency rate has a significant negative effect on the dynamic correlation between international and local prices in all panel models. This indicates that a high SSR in wheat helps reduce volatility pass-throughs from the global market. Therefore, by adopting practices that increase the level of its wheat self-sufficiency rate, the government of a wheatimporting country can diminish the impact of unexpected excess volatility from international markets on its local markets. A point that that must made here is that this paper focused on the connectivity between the degree of price spill-overs and selfsufficiency in wheat, not between the extent of price passthroughs and food policy changes. The panel method estimates coefficients, simultaneously comparing results both between regions and years. All 10 selected countries may not have necessarily altered food policy regimes, such as boosting export taxes, although policy information on the subject was not fully available for these nations during the sample period. Accordingly, the outcomes should not be simply interpreted as showing that any autarky policy assists local market stabilization. Nonetheless, it suggests that such policy measures may be useful for reducing price volatilities in domestic markets. For future research, import tariff or a dummy variable might be used as an explaining variable in the model.

This evidence that increasing the SSR of an agricultural commodity is effective in isolating the domestic market is valuable for policymakers in food importing countries. The primary beneficiaries of implementing the policy measure are risk-averse producers and consumers because their utility or welfare improves as the price volatility of foodstuffs declines. While this paper makes these key interventions, several tasks remain. The Arrow-Pratt coefficient, a measure of risk preference intensity, needs to be estimated to gauge the monetary values of the benefit from stabilized price movements ${ }^{31}$. Another subject that needs to be discussed is the cost to raise the SSR. While the potential cost

Table 11 Specification tests of panel estimation

\begin{tabular}{|c|c|c|c|c|}
\hline & Hausman test & $\begin{array}{l}\text { Modified Wald test for group-wise } \\
\text { heteroskedasticity }\end{array}$ & $\begin{array}{l}\text { Pesaran's test of cross-sectional } \\
\text { independence }\end{array}$ & $\begin{array}{l}\text { Wooldridge test for } \\
\text { autocorrelation }\end{array}$ \\
\hline Statistics & 0.120 & $2536.480^{\star \star \star}$ & $1.973^{\star \star}$ & $15.096^{\star \star \star}$ \\
\hline
\end{tabular}


Table 12 Estimation results of panel data analysis

\begin{tabular}{llll} 
& Random effects model & $\begin{array}{l}\text { Prais-Winsten regression } \\
\text { with PCSEs }\end{array}$ & $\begin{array}{l}\text { FGLS model with heteroskedasticity } \\
\text { and autocorrelation }\end{array}$ \\
\hline$S S R\left(k_{1}\right)$ & $-0.072^{\star \star}(0.035)$ & $-0.059^{\star}(0.034)$ & $-0.045^{\star \star \star}(0.011)$ \\
$G D P\left(k_{2}\right)$ & $0.051(0.069)$ & $0.137(0.130)$ & $0.118^{\star \star \star}(0.022)$ \\
$C P I\left(k_{3}\right)$ & $-0.104(0.162)$ & $-0.143^{\star}(0.081)$ & $-0.161^{\star \star \star}(0.039)$ \\
$\Delta M C\left(k_{4}\right)$ & $0.004(0.009)$ & $0.014(0.019)$ & $-0.001(0.004)$ \\
$\Delta R C\left(k_{5}\right)$ & $-0.004(0.024)$ & $-0.002(0.018)$ & $0.013(0.007)$ \\
Constant $(c)$ & $0.208(0.038)$ & $0.196^{\star \star \star}(0.021)$ & $0.193(0.007)$ \\
$R^{2}$ & 0.03 & 0.179 & - \\
Wald test & 6.53 & 7.61 & $59.31^{\star \star \star}$ \\
Observations & 80 & 80 & 80 \\
\hline Notes: $\left(^{\star}\right),\left(^{\star \star}\right)$, and $\left.~^{\star \star \star *}\right)$ denote statistical significance at the $10 \%, 5 \%$, and 1\% levels, respectively. The values in parentheses are standard errors and the random effect model is adjusted for 10 clusters
\end{tabular}

to achieve a targeted SSR may vary across countries, it is likely to be substantial in cases in which farmers are continuously given subsidies to stimulate crop production or raise import tariffs and refuse cheaper foreign products. As Tanaka (2018) suggests, a revenue-neutral approach of increasing tax revenues by raising import tariffs that are then expended as subsidies for agricultural production may increase household welfare and lower its variance without hurting the government's budget. However, evidence on this topic has only been obtained for the Egyptian economy and this is not applicable to all nations or regions. Thus, the cost benefit of the policy has not been fully analyzed and therefore calls for future studies. On the other hand, although Bai and Perron's (2003) structural breaks test is used to identify the structural changes in each price return, the main weakness of the GARCH model is that it assumes that conditional volatility is based on only one regime over the sample period. In light of this, it would be interesting to apply a Markovswitching $\mathrm{GARCH}^{32}$, which has the advantage of allowing for time-varying causality across regime (structural) changes to estimate volatility. This would enable the present study's findings to be compared with the empirical results derived from different models. However, this exercise must be left for a future research project.

\section{Data availability}

The datasets generated and analyzed in this study are available in the Global Informationand Early Warning System repository: http://www.fao.org/giews/en/; and World Development Indicators, accessed at: http://www.worldbank.org/data/. The data that support the findings of this study can be obtained from the corresponding author upon request.

Received: 9 May 2019; Accepted: 1 October 2019; Published online: 22 October 2019

\section{Notes}

1 Bellemare (2014) econometrically proves the relationship between food prices and social unrest, such as food riots.

2 X-13-ARIMA is the U.S. Census Bureau's software package for seasonal adjustment. 3 Dickey and Fuller (1979).

4 Kwiatkowski et al. (1992) and Phillips and Perron (1988).

5 The ADF and KPSS unit root tests indicate that all the variables have unit root processes in their levels. These results were not reported for sake of brevity. The results can be obtained from the authors upon request.

6 See Bai and Perron (2003).

7 http://www.fao.org/faostat/en/\#home.

8 David and Amir (2017) use the same method to obtain yearly DCC by taking the average of the monthly DCC.
9 Inflation is the annualized growth rate of the consumer price index (CPI).

10 World Development Indicators are available at: http://www.worldbank.org/data/ onlinedatabases/onlinedatabases.html.

11 This empirical technique has been widely applied in the examination of stock and commodity markets (see, for example, Tamakoshi and Hamori, 2014).

12 See Bollerslev (1986) for details on the GARCH model.

13 See, for example, the surveys by Bauwens et al. (2006). GARCH models are useful in studying volatility spill-over in financial markets (e.g., Lin et al., 1994; Koutmos and Booth, 1995; Karolyi and Stulz, 1996; Booth et al., 1997; Cha and Jithendranathan, 2009; Guo, 2014) and energy markets (Ewing et al., 2002; Worthington et al., 2005; Sadorsky, 2006; Malik and Hammoudeh, 2007; Elder and Serletis, 2009; Cifarelli and Paladino, 2010; Basher and Sadorsky, 2016).

14 See Cheung and $\mathrm{Ng}$ (1996) for details on a two-step procedure to test for causality. 15 See, for example, Chiang et al. (2007), Savva (2009), Lahrech and Sylwester (2011), Antonakais (2012), Apostolakis and Papadopoulos (2014), Basher and Sadorsky (2016), and Guo (2018).

16 The A-DCC model modified the original DCC model by including asymmetries in the correlation dynamics. See Cappiello et al. (2006) for an extensive analysis of these models' advantages. See Tamakoshi and Hamori (2013) for the estimation procedure of the A-DCC mode.

17 The AG-DCC and G-DCC models account for heteroskedasticity when estimating the correlation coefficients.

18 See Bollerslev and Wooldridge (1992).

19 BFGS (Broyden, Fletcher, Goldfarb and Shanno) is a quasi-Newton optimization method that uses information about the gradient of the function at the current point to calculate where to find a better point. All GARCH computations are carried out using WinRATS 8.1.

$20 \mathrm{ADF}$ unit root tests, though not reported here, indicated that all variables in Eq. (16) were stationary.

21 See Maddala and Mount (1973) and Baltagi (1981)

22 For details about the model selection, see the note for Table 5. The results of the lag selection are not reported here for the sake of brevity. The results can be obtained from the authors upon request.

23 As suggested by Hansen and Lunde (2005), it is reasonable to include four combinations of lag length $p, q=1,2$ for most GARCH models. They also indicated that models with more lag will not result in more accurate forecasts than more parsimonious models. Moreover, Tamakoshi and Hamori (2014) also applied the same lag selection to estimate the AR-GARCH model.

24 The AR (1)-GARCH $(1,1)$ model was chosen for each price series because it has the lowest BIC value.

25 A significant causality was also detected from lag 1 to lags $10(m=10)$ and 15 $(m=15)$; therefore, we chose the shortest lag length.

26 There is also no statistically significant evidence of causality from local price to international price at all lags.

27 One of the major advantages of the CCF approach is that it allows researchers to investigate both causality-in-mean and causality-in-variance (Tamakoshi and Hamori, 2014). The squared standardized residuals are used to test the null hypothesis that there is no causality-in-variance. The results of causality-in-variance tests are reported in Table 6. We find significant unidirectional causality-in-variance form international wheat price to local price in Cameroon and Kyrgyzstan. In contrast, no causality-in-variance exists between international and local prices in the other eight countries.

28 Georgia's self-sufficiency rate of wheat in Fig. 2 exhibits a low level.

29 See Table 4 and Fig. 2.

30 See Table 2

31 See Fox et al. (1999) for detailed explanations on the Arrow-Pratt coefficient.

32 See Hamilton and Susmel (1994) for details. 


\section{References}

Abbott PC, Christopher H, Wallance ET (2008) What's Driving Food Prices? Farm Foundation issue report no. 37951, Farm Foundation. https://www1.eere. energy.gov/bioenergy/pdfs/farm_foundation_whats_driving_food_prices.pdf. Accessed 4 Sep 2019

Abdulai A (2000) Spatial price transmission and symmetry in the Ghanaian maize market. J Dev Econ 63(3):327-349

Antonakais N (2012) Exchange return co-movements and volatility spillovers before and after the introduction of euro. J Int Financial Mark Inst Money 22 (5):1091-1109

Apostolakis G, Papadopoulos AP (2014) Financial stress spillovers in advanced economies. J Int Financial Mark Inst Money 32(C):128-149

Bai J, Perron P (2003) Computation and analysis of multiple structural change models. J Appl Econ 18(1):1-22

Baltagi BH (1981) Simultaneous equations with error components. J Econ 17 (2):189-200

Basher SA, Sadorsky P (2016) Hedging emerging market stock prices with oil, gold, VIX and bonds: a comparison between DCC ADCC and GO-GARCH. Energy Econ 54(C):235-247

Baulch B (1997) Transfer costs, spatial arbitrage and testing for food market integration. Am J Agric Econ 79(2):477-487

Bauwens L, Laurent S, Rombouts JVK (2006) Multivariate GARCH models: a survey. J Appl Econ 21(1):79-109

Bar-Shira Z, Just RE, Zilberman D (1994) Estimation of farmers' risk attitude: an econometric approach, Department of Agricultural and Resource Economics working paper no. 94-36, University of Maryland College Park. http:// ageconsearch.umn.edu/record/197812/files/agecon-maryland-94-36.pdf. Accessed 1 July 2019

Beck N, Katz JN (1995) What to do (and not to do) with time series cross-section data. Am Political Sci Rev 89(3):634-647

Bellemare M (2014) Rising food prices, food price volatility and social unrest. Am J Agric Econ 97(1):1-21

Bishwajit G, Sarker S, Kpoghomou M, Gao H, Jun L, Yin D (2013) Self-sufficiency in rice and food security: a South Asian perspective. Agric Food Security 2 (1): 10

Bollerslev T (1986) Generalized autoregressive conditional heteroskedasticity. J Econ 31(3):307-327

Bollerslev T, Wooldridge JM (1992) Quasi-maximum likelihood estimation and inference in dynamic models with time-varying covariances. Econom Rev 11 (2):143-172

Booth GG, Martikainen T, Tse Y (1997) Price and volatility spillovers in Scandinavian stock markets. J Bank Financ 21(6):811-823

Bouët A, Debucquet DL (2012) Food crisis and export taxation: the cost of noncooperative trade policies. Rev World Econ 148(1):209-233

Cappiello L, Engle RF, Sheppard K (2006) Asymmetric correlations in the global equity and bond returns. J Financ Econ 4(4):537-572

Ceballos F, Hernandez MA, Minot N, Robles M (2017) Grain price and volatility transmission from international to domestic markets in developing countries. World Dev 94(C):305-320

Cha HJ, Jithendranathan T (2009) Time-varying correlations and optimal allocation in emerging market equities for the US investor. Int J Financ Econ 14 (2):172-187

Clarete RL, Adriano L, Esteban A (2013) Rice trade and price volatility: implications on ASEAN and global food security, ADB Economic working paper no. 368. https://www.adb.org/sites/default/files/publication/30390/ewp-368.pdf. Accessed 1 Apr 2019

Chiang TC, Jeon BN, Li H (2007) Dynamic correlation analysis of financial contagion: evidence from Asian markets. J Int Money Financ 26(7):1206-1228

Cheung Y-W, Ng LK (1996) A causality-in-variance test and its application to financial market prices J Econ 72(1-2):33-48

Clapp J (2017) Food self-sufficiency: making sense of it and when it makes sense. Food Policy 66:88-96

Clapp J (2015) Food self-sufficiency and international trade: a false dichotomy?, Food and Agriculture Organization of the United Nations. http://www.fao. org/3/a-i5222e.pdf. Accessed 10 Mar 2019

Cifarelli G, Paladino G (2010) Oil price dynamics and speculation: a multivariate financial approach. Energy Econ 32:363-372

Conforti P (2004) Price transmission in selected agricultural markets, commodity and trade policy research, FAO Commodity and Trade Policy Research working paper no. 7. http://www.fao.org/tempref/docrep/fao/006/ad766e/ ad766e00.pdf. Accessed 15 Feb 2019

Cooke B, Robles R (2009) Recent Food Prices Movements: A Time Series Analysis, International Food Policy Research Institute discussion paper no. 00942. International Food Policy Research Institute: Washington, DC

Cramer GL, Hansen JM, Wailes EJ (1999) Impact of rice tariffication on Japan and the world rice market. Am J Agric Econ 81(5):1149-1156

David LB, Amir R (2017) Stocks and bonds during the gold standard. Econ Lett 159(C):119-122
Delva JG, Loney J (2008) Haiti's government falls after food riots. Reuters. https:// www.reuters.com/article/us-haiti/haitis-government-falls-after-food-riotsidUSN1228245020080413. Accessed 20 Feb 2019

Dickey DA, Fuller WA (1979) Distribution of the estimators for autoregressive time series with a unit root. J Am Stat Assoc 74(366):427-431

Elder J, Serletis A (2009) Oil price uncertainty in Canada. Energy Econ 31 (6):852-856

Engle RF (2002) Dynamic conditional correlation: a simple class of multivariate generalized autoregressive conditional heteroscedasticity models. J Bus Econ Stat 20(3):339-350

Ewing BT, Malik F, Ozfidan O (2002) Volatility transmission in the oil and natural gas markets. Energy Econ 24(6):525-538

Fox G, Turner J, Gillespie T (1999) The value of precipitation forecast information in winter wheat production. Agric For Meteorol 95:99-111

Götz L, Glauben T, Brümmer B (2013) Wheat export restrictions and domestic market effects in Russia and Ukraine during the food crisis. Food Policy 38 (C):214-226

Guo J (2014) Causal relationship between stock returns and real economic growth in the pre- and post- crisis period: evidence from China. Appl Econ 47(1):12-31

Guo J (2018) Co-movement of international copper prices, China's economic activity and stock returns: Structural breaks and volatility dynamics. Glob Financ J 36(C):62-77

Hamilton WH (1918) The requisites of a national food policy. J Political Econ 26 (6):612

Hamilton JD, Susmel R (1994) Autoregressive conditional heteroskedasticity and changes in regime J Econ 64(1-2):307-333

Hansen PR, Lunde A (2005) A forecast comparison of volatility models: does anything beat a GARCH (1,1)? J Appl Econ 20(7):873-889

Hatzenbuehler PL, Abbott PC, Abdoulaye T (2017) Price transmission in Nigerian food security crop markets. J Agric Econ 68(1):143-163

Headey D, Fan S (2008) Anatomy of a crisis: the causes and consequences of surging food prices. Agric Econ 39(1):375-391

Hong Y (2001) A test for volatility spillover with applications to exchange rates J Econ 103(1-2):183-224

International Rice Research Institute (2008) The RiceCrisis: What Needs to be Done?, International Rice Research Institute background paper no. 12. http:// unpan1.un.org/intradoc/groups/public/documents/apcity/unpan034789.pdf. Accessed 4 Sep 2019

Ivanic M, Martin W (2008) Implications of higher global food prices for poverty in low-income countries. Agric Econ 39(1):405-416

Jianakoplos NA, Bernasek A (1998) Are women more risk averse? Econ Inq 36 (4):620-630

Kako T (2009) Sharp decline in the food self-sufficiency ratio in Japan and its future prospects, paper presented at the International Association of Agricultural Economists Conference, Beijing, 16-22 August

Koutmos G, Booth GG (1995) Asymmetric volatility transmission in international stock markets. J Int Money Financ 14(6):747-762

Karolyi GA, Stulz R (1996) Why do markets move together? An investigation of US-Japan stock return comovements. J Financ 50(3):951-986

Keynes J (1993) National self-sufficiency. Yale Rev 22(4):755-769

Kwiatkowski D, Phillips PCB, Schmidt P, Shin Y (1992) Testing the null hypothesis of stationarity against the alternative of a unit root. J Econ 54:159-178

Lahrech A, Sylwester K (2011) US and Latin American stock market linkages. J Int Money Financ 30(7):1341-1357

Lin W, Engle R, Ito T (1994) Do bulls and bears move across borders? International transmission of stock returns and volatility. Rev Financial Stud 7 (3):507-538

Ljung GM, Box GEP (1978) On a measure of lack of fit in time series models. Biometrika 65(2):297-303

Lutz C, Kuiper WE, van Tilburg A (2006) Maize market liberalisation in Benin: a case of hysteresis. J Afr Economies 16(1):102-133

Maddala GS, Mount TD (1973) A comparative study of alternative estimators for variance components model used in econometric application. J Am Stat Assoc 68(342):324-328

Malik S, Hammoudeh S (2007) Shock and volatility transmission in the oil US and Gulf equity markets. Int Rev Econ Financ 16(3):357-368

Minot N (2011) Transmission of World Food Price Changes to Markets in SubSaharan Africa, IFPRI discussion paper no. 1059, International Food Policy Research Institute: Washington, DC

Mitchell D (2008) A Note on Rising Food Prices, World Bank Policy research working paper no. 4682. Available at: https://papers.ssrn.com/sol3/Delivery. cfm/4682.pdf. Accessed 5 Sep 2019

Moser C, Barrett C, Minten B (2009) Spatial integration at multiple scales: rice markets in Madagascar. Agric Econ 40(3):281-294

Mundlak Y, Larson D (1992) On the transmission of world agricultural prices. World Bank Econ Rev 6(3):399-422

Myers RJ (2013) Evaluating the effectiveness of inter-regional trade and storage in Malawi's private sector maize markets. Food Policy 41(C):75-84 
Meyers WH and Meyer S (2008) Causes and Implications of the Food Price Surge, Food and Agricultural Policy Research Institute University of Missouri report no. 12-08. https://papers.ssrn.com/sol3/Delivery.cfm/4682.pdf. Accessed 5 Sep 2019

Naylor RI, Falcon WP (2010) Food security in an era of economic volatility. Popul Dev Rev 36(4):693-723

Newey WK, West KD (1994) Automatic lag selection in covariance matrix estimation. Rev Economic Stud 61(4):631-653

Pesaran MH (2004) General Diagnostic Tests for Cross Section Dependence in Panels, Cambridge Economics working paper no. 0435, Cambridge University: Cambridge

Phillips PC, Perron P (1988) Testing for a unit root in time series regression. Biometrika 75(2):335-346

Piesse J, Thirtle C (2009) Three bubbles and a panic: an explanatory review of recent food commodity price events. Food Policy 34(2):119-129

Sadorsky P (2006) Modeling and forecasting petroleum futures volatility. Energy Econ 28(4):467-488

Savva CS (2009) International stock markets interactions and conditional correlations. J Int Financial Mark Inst Money 19(4):645-661

Tamakoshi G, Hamori S (2013) An asymmetric dynamic conditional correlation analysis of linkages of European financial institutions during the Greek sovereign debt crisis. Eur J Financ 19(10):939-950

Tamakoshi G, Hamori S (2014) Causality-in-variance and causality-in-mean between the Greek sovereign bond yields and Southern European banking sector equity returns. J Econ Financ 38(4):627-642

Tanaka T (2018) Agricultural self-sufficiency and market stability: a revenueneutral approach to wheat sector in Egypt. J Food Security 6(1):31-41

Tanaka T, Hosoe N (2011) Does agricultural trade liberalization increase risks of supply-side uncertainty?: effects of productivity shocks and export restrictions on welfare and food supply in Japan. Food Policy 36(3):368-377

Trostle R (2008) Global agricultural supply and demand: Factors contributing to the recent increase in food commodity prices. USDA Economic Research Service working paper no. 0801. https://www.ers.usda.gov/webdocs/ publications/40463/12274_wrs0801_1_.pdf?v=0. Accessed 11 Feb 2019

Van Dijk D, Osborn DR, Sensier M (2005) Testing for causality in variance in the presence of breaks. Econ Lett 89(2):193-199

Von Braun J, Ahmed AU, Asenso-Okyere K, Fan S, Gulati A, Hoddinott JF, Pandya-Lorch R, Rosegrant MW, Ruel MT, Torero M, Van Rheenen T, Von Grebmer K (2008) High Food Prices: The What, Who, How of Proposed Policy Actions, International Food Policy Research Institute Policy Brief. http://ebrary.ifpri.org/cdm/ref/collection/p15738coll2/id/10384. Accessed on 4 Sep 2019

Wooldridge JM (2010) Econometric analysis of cross section and panel data. MIT Press, Cambridge

Worthington A, Kay-Spratley A, Higgs H (2005) Transmission of prices and price volatility in Australian electricity spot markets: a multivariate GARCH analysis. Energy Econ 27(2):337-350

Yamashita K (2016) Will Japanese agriculture be able to survive? The Canon Institute for Global Studies column 22 August. https://www.canon-igs.org/en/ column/macroeconomics/20160822 3913.html. Accessed 15 Feb 2019
Yang J, Qiu H, Rozelle S (2008) Fighting global food price rises in the developing world: the response of China and its effect on domestic and world markets. Agric Econ 39(1):453-464

\section{Acknowledgements}

The authors are grateful to Professor Michiel Keyzer for comments on an early version of this paper. The research of the second author is in part supported by a Grant-in-Aid from the Japan Society for the Promotion of Science (Grant Number (A) 18K14533)

\section{Author contributions}

J.G. and T.T. designed the research. J.G. constructed the econometric model and edited the program code for analyzing. J.G. also analyzed and interpreted the data regarding the common determinants of wheat price volatility transmission from international to local markets in wheat-importing countries. T.T. conceived the study with inspiration from his previous studies. T.T. also performed the background of the paper and discussed the policy implications of the empirical results. The authors equally contributed to this work.

\section{Competing interests}

The authors declare no competing interests.

\section{Additional information}

Correspondence and requests for materials should be addressed to J.G.

Reprints and permission information is available at http://www.nature.com/reprints

Publisher's note Springer Nature remains neutral with regard to jurisdictional claims in published maps and institutional affiliations.

(c) (i) Open Access This article is licensed under a Creative Commons Attribution 4.0 International License, which permits use, sharing, adaptation, distribution and reproduction in any medium or format, as long as you give appropriate credit to the original author(s) and the source, provide a link to the Creative Commons license, and indicate if changes were made. The images or other third party material in this article are included in the article's Creative Commons license, unless indicated otherwise in a credit line to the material. If material is not included in the article's Creative Commons license and your intended use is not permitted by statutory regulation or exceeds the permitted use, you will need to obtain permission directly from the copyright holder. To view a copy of this license, visit http://creativecommons.org/ licenses/by/4.0/.

(C) The Author(s) 2019 